\title{
Reinvesting Government: Financing Options for Military Base Redevelopment
}

\author{
Kenneth N. Hansen and Theodore J. Stumm
}

This paper explores the issues of "privatization in place" versus public enterprise with regard to military base redevelopment. Three case studies are used to examine three research proposals having to do with public involvement, market solutions and policy outcomes. We find that while politically popular, privatization provides little in the way of civilian job creation and income replacement at former military bases. Instead, the case of Alexandria, Louisiana, supports the idea that public enterprise authorities can and do provide economic recovery for their communities. The federal government seems to agree given that privatization was not an option for base conversions in the 2005 closure round.

For much of the last thirty years or so, government has been under assault by those who favor market solutions to public policy problems. Government is often portrayed by the media as inefficient, wasteful and expensive. Privatization, on the other hand, is seen as a more rational, costeffective solution. This has contributed to the fervor behind "reinventing government" and public sector downsizing. In the midst of this movement came the end of the Cold War and subsequent reductions in defense spending, particularly on military personnel, which were reduced by almost a third. At the same time, domestic military base infrastructure was reduced by 15 percent through the Base Realignment and Closure (BRAC) process. This paper examines the applicability of "privatization in place"-defined by the Pentagon as "redirecting" the base mission using private contractors and former base employees to do the work at existing facilities (IBASC 1995; Pidgeon 1996) as a solution to defense downsizing - and finds it severely lacking in substance and outcomes. Instead, we offer the notion that base conversion implemented in the form of public enterprise is a more optimal solution.

These issues are first discussed theoretically by integrating ideas taken from the areas of defense policy and urban development. We then examine three research proposals with case studies and some empirical data provided by the then-General Accounting Office [now Government Accountability Office]. Data were collected from participant-observation, personal interviews, journalistic sources and government documents. The cases of

KENNETH N. HANSEN is assistant professor of political science at California State University, Fresno. THEODORE J. STUMM, Colonel, USAF (Ret), is chair of the Department of Political Science and Public Administration at the University of North Florida.

The American Review of Politics, Vol. 26, Winter, 2005-06: 405-423

(C)2005 The American Review of Politics 
San Antonio, Texas, and Sacramento, California, illustrate the pitfalls of privatization in place, while Alexandria, Louisiana, illustrates the potential benefits of public enterprise and mixed public-private solutions.

\section{Literature Review}

In recent years privatization has taken hold of the field of public administration, both in theory and in practice. Public choice theorists and Downsian rationalists have infiltrated the ivory tower (Goodsell 2004), while reinventing government through contracting out and downsizing has captivated politicians and the general public, especially at the local level. The key assumption of those who advocate privatization is that government is inefficient and unresponsive (Friedman and Friedman 1979; Osborne and Gaebler 1992). Public administrationists sometimes echo the mantra of neo-conservative free-market economists, who argue that markets are more efficient than government (Goodsell 2004).

But this is by no means a unanimous view, as evidenced by the many detractors (Fox and Miller 1995; Blanchard et al. 1998; Miller and Simmons 1998; Stumm and Thomas 1999; Goodsell 2004) many of whom are discourse theorists and democratic administrationists who argue that privatization seeks to subvert the legitimacy of government. The proponents of privatization are also challenged by a substantial body of work in the area of urban politics. Much of the urban policy literature asserts that what local governments do is focused on economic development, mostly in the form of job creation and income generation (Stein 1990; Herson and Bolland 1996; Judd and Kantor 1997). Moreover, those who subscribe to what is called the "regime paradigm" argue that cities have a normative conception of what they want to be like and how they want to be perceived by others. These "perceptual orbits" dictate the choices made regarding developmental policy (Stone and Sanders 1987; Pagano and Bowman 1995).

Much of local economic development policy is implemented by public enterprises, not private contractors. Public enterprises are governmentowned corporations, such as public utility companies. But they often can be found in the form of port authorities and economic development corporations, which provide incentives for development and facilitate the fulfillment of a community's perceptual orbit. These incentives often include tax increment financing and abatements, freeports or enterprise zones. Some government enterprises require subsidization, but a majority generate annual surpluses which help to defray local tax burdens and provide services in-kind (Stumm 1996). Many public corporations of this type are targets of privatization by special interests. Public utilities such as water, electric and solid waste are often particularly attractive if they have positive cash flows. 


\section{Base Closure and Conversion Politics}

One area in which the practices of privatization and government enterprise are pitted against each other is military base redevelopment policy. The allocation of domestic defense infrastructure has traditionally been viewed as a closed, distributive process, dominated by elites controlling an "iron triangle" which administer resources in ways that are seldom visible or controversial (Ripley and Franklin 1995). But this view is changing for three reasons having to do with 1) academic views of defense administration, 2) the revision of rules which govern policy, and 3) the perceived redistributive nature of base closure politics.

First, few have challenged the accepted view of defense administration as a closed process with few actors. Mayer and Khademian (1996) argue that Huntington's (1961) view of defense policy as a more open process is gaining wider acceptance than it did in the 1960s. They also assert that the topic of defense administration has largely been ignored in political science and public administration for over twenty years. This may be the reason why the closed policy subsystem view predominated for so long: Few sought to challenge it.

Second, the rules often dictate who can play and who cannot. Steve Koven (1992) describes how changing the rules through the BRAC (Base Realignment and Closure) commission process, has allowed a greater number of actors into the debate over the allocation of base structure resources. Ostensibly created to remove partisan politics from what was seen as an administrative function, the BRAC process instead had the effect of displacing politics from Congress to the BRAC commission. ${ }^{1}$ By removing the politics from Congress to the commission, elected officials from all levels of government were then able to act as advocates against base closure and use bureaucracy as a foil for their own benefit, regardless of success or failure. In this way they resolved their own "collective dilemmas" (Mayer 1995; Sorenson 1998; Goren 2003; Hansen 2004).

The third reason why defense infrastructure allocations have become more open is due to the perceived redistributive nature of the policy. Redistributive policies, such as taxes and welfare for example, are more contentious and generate higher levels of visibility and salience. They are also much more amenable to special interest politics (Lowi 1969). When it comes to base closures and subsequent redevelopment, some localities win in the sense that they are allowed to keep their bases, whereas others lose, having fallen victim to closure decisions and becoming the recipients of booby prizes in the form of redevelopment grants.

By 1995, ninety-seven major military installations had been designated for closure by four separate BRAC commissions (CBO 1996), causing a 
great deal of local shock, alienation and uncertainty. Into this now highly charged political context walked President Clinton. According to the BRAC legislation, the president must either accept or reject the entire closure "hit list" as provided for by the commission and ratified by Congress. This he did. But following this procedure, he gave in to pressure regarding the realignments of Kelly and McClellan Air Force Bases in Texas and California, respectively, by allocating million dollar grants for the purpose of privatizing in place the work done at the bases. This was done despite the fact that the only previous experience at privatization in place was just beginning at Newark Air Force Base, Ohio, which had housed a small inertial guidance system maintenance depot. However, both of these states were seen to be crucial to the president's reelection effort. In short, the solution in these two cases was to subvert, in a somewhat general sense, the spirit of BRAC by attempting to keep bases open in a slightly modified form. ${ }^{2}$

\section{Privatization versus Public Enterprise}

The goals of privatized administration are similar to those of administrative orthodoxy: efficiency, accountability, hierarchy, span of control and the like. The key difference involves replacing burdensome codified rules with the more common-law orientation of the market (Gortner et al. 1997). Whereas in Britain and Europe privatization refers to the reversion of entire sectors to the marketplace, in the U.S. it generally refers to the private provision of public goods with public financing (Morgan and England 1988). The reality is that many governments prefer to contract with other governmental entities or the non-profit sector, in lieu of private companies (Ferris and Graddy 1986).

Public enterprises are those business-like operations of government that provide goods and services on an exchange basis. Cities have been using such enterprises since the earliest days of the republic to provide revenue for municipal needs. The earliest enterprises were toll roads, canals, and harbor facilities that both facilitated transportation and trade and provided funds for the cities that operated them (Paul 1992). Municipal enterprises today encompass a wide array of goods and services from utilities to recreation facilities and community development activities. These municipal enterprises provide a number of advantages for cities. They are largely self-supporting, may provide capital for their infrastructure and growth needs through revenue bonds rather than municipal general obligation bonds, and they generate significant amounts of revenue (Gitajn 1984; Pierce and Rust 1991). Although this revenue must be transferred to other municipal funds prior to use for non-enterprise activities, it nonetheless constitutes a significant portion of municipal revenues for cities that employ such enterprises (Stumm 
1996). As community development agencies, municipal enterprises have proven successful in a wide variety of circumstances, and can function well in inter-local settings.

\begin{abstract}
Method
The realignment of the San Antonio Air Logistics Center (ALC) at Kelly Air Force Base in San Antonio, Texas, and the closure of England Air Force Base in Alexandria, Louisiana, contrast the two military base redevelopment solutions used in this article. Preliminary data for both case studies were gathered primarily by participant observation through the Texas Tech University Military Base Conversion and Community Assistance Program from July 1995 through February 1997. These were augmented by government documents, and for the sake of clarity, personal and telephone interviews of relevant policy actors in the base conversion and realignment process. For the sake of additional comparison, data on the privatization of the Sacramento Air Logistics Center at McClellan AFB, California, and additional quantitative data for all three cases were collected through the University of North Florida's Military Adjustment Study Group from July 1997 through April 2002.

Cases were selected on the basis of the key causal variable (King, Keohane and Verba 1994), which is the type of solution chosen by the community to deal with the problem of base closure. The cases of Kelly and McClellan Air Force Bases represent the entirety of major privatized Air Logistics Centers resulting from the BRAC process. If privatization of such facilities is going to work, it has to work at these two locations. The case of Alexandria, Louisiana, is used to provide an example of a successful base conversion operating as a municipal enterprise. One advantage that Alexandria may have is that it was a victim of the 1991 BRAC and hence has had a four-year head start on the other two, which were victims of the 1995 BRAC. Nevertheless, more than a decade has gone by since the 1995 BRAC decisions, which is long enough to see if the intended effects of privatization were realized. All figures used in the quantitative comparison are 2002 data, the most recent year for which such figures are available.

The main research question of the work is whether privatization in place is a viable solution for base closings and realignments. Of concern is whether privatization is in the public interest and whether it realizes the efficiency its proponents claim. Also at issue is whether better alternatives exist. Most base conversions are mixed public/private solutions governed by Local Reuse Authorities (LRAs) who administer the property and conversion plans as public authorities (Hansen et al. 1997; Hansen 2004). Some of these are incorporated as special districts or public enterprises that have the
\end{abstract}


power to issue bonds and negotiate leases, which might give them a potential institutional capacity competitive with or greater than large private corporations. In pursuit of an answer to what is more appropriate, we have three research propositions:

- RP1: The process by which communities choose base conversion solutions to mediate base closure reflects the will of the community.

- RP2: Privatization replaces jobs and income lost as a result of BRAC actions.

- RP3: Public enterprise is a viable alternative to privatization.

\section{Defense Privatization}

In 1995, the realignment of the Air Logistics Centers at Kelly AFB and McClellan AFB struck their respective communities of San Antonio and Sacramento very hard. Why should this be any different from any other base closure? The answer is that such maintenance depots employ a great number of civilians. The only other military bases that come close to employing as many civilians are naval shipyards (Sorenson 1998). Hence, the overall negative economic effects were thought to be potentially greater at these locales than in other communities. A solution to this problem, which was supported by the Clinton Administration, was to privatize the work done at these facilities, so as not to cause widespread disruption to the local communities.

The reasons for this are obvious. Clinton was up for reelection the following year. California and Texas are the two biggest states in the Electoral College. San Antonio, in particular, has a large number of Hispanics, upon which Clinton was relying to help win the state (he did not). Also, the idea of smaller government is a popular one among the electorate. By supporting privatization, President Clinton could appear to be ideologically conservative and enhance his "New Democrat" credentials during his 1996 reelection campaign. With regard to the details he was especially vague, but gave the impression that private contractors would take over as the military pulled out, creating little displacement among personnel (Sorenson 1998, 69-71).

But the practicality of the eventual implementation of this idea brings up our research question: Can privatization effectively replace lost jobs and income as a result of base closure? Or are there other alternatives? While the apparent rationality of privatization would seem to indicate a positive outcome, this is by no means guaranteed.

To date, the military's experience with privatization is largely limited to support services due to possible overseas deployment and rotation 
requirements for operational units. Typically competitive bids are taken from prospective private contractors and compare them with the current government service provider. Savings from this practice are unknown, but estimated to be at $\$ 1.5$ billion a year, although it should be noted that most of the evidence is anecdotal (CBO 1997). The Congressional Budget Office argues that savings through competitive bidding are likely due to the fact that the process is short-term. Proponents of defense privatization favor long-term contracts of up to ten years, which might negate initial savings and efficiency, especially if performance was poor or inadequate (CBO 1997).

The only previous experience with privatization in place at a former base came in 1993 with the closure of the minor installation of Newark AFB in Ohio. It is interesting to note that Both Kelly AFB in San Antonio, and McClellan AFB in Sacramento, as well as Newark AFB in Ohio are the only three bases proposed for privatization in place and that all three were at that time were Air Force Materiel Command (AFMC) bases. The commander of AFMC at that time, General Henry Viccellio, Jr., described privatization as "the conversion of public sector activities, capabilities, and/or facilities to private industry, while maintaining the appropriate level of government oversight to ensure protection of public interest and desired levels of performance" and "the use of excess public sector capacities, equipment, and facilities by private industry, while maintaining appropriate standards of maintenance, safety, and environmental compliance" (cited in Pidgeon 1996).

Sorenson provides an excellent description and argument against such privatization with this example. The mission of Newark AFB was primarily a missile and aircraft guidance calibration center. It was among the smallest of all Air Force bases, and had a highly specialized mission. Despite the options of keeping the facility or redirecting the mission to neighboring Wright-Patterson AFB, BRAC approved privatization and the transfer of operations to Rockwell International (later acquired by Boeing) and Wyle Laboratories. Sorenson alleges that this experiment cost taxpayers " $\$ 456$ million more than if the base were kept in Air Force hands" (Sorenson 1998, 70). The reason why this case is worthy of note is because it was considered to be an example of success by the Clinton Administration in its effort to legitimize privatization at Kelly and McClellan AFBs.

\section{San Antonio's Privatization in Place}

San Antonio is a major city of about a million people and is located between South Texas and the Hill Country of central Texas. In the spring of 1995, the greater San Antonio community was faced with a somewhat 


\section{2 | Kenneth N. Hansen and Theodore J. Stumm}

unique situation: two of the five military bases in that community were indirectly placed in competition with one another. This was because both Brooks AFB and Kelly AFB were under consideration for downsizing, despite their different missions. Of the two, Brooks was considered the most vulnerable, while the possibility of the closure or realignment of Kelly was considered a long shot.

Like other communities, San Antonio engaged in a dual-track base retention and conversion planning strategy, although at the time it was denied so as not to send the wrong message to BRAC, according to retired General Paul Roberson, who was then-Chairman of the Chamber of Commerce. However, it was still an unexpected shock when BRAC announced that Kelly AFB would be realigned, while Brooks was spared. Of particular concern were the nearly 12,000 jobs at Kelly and the potential economic and political consequences of their departure. Most of the people employed at Kelly were Hispanic, which contributed to the highly charged political aspect of the realignment and subsequent conversion plans.

The lead institutions in the privatization effort were the City of San Antonio, the Office of Defense Transition, the San Antonio Chamber of Commerce, and the U.S. Air Force. The chairs and vice chairs of the subcommittees include representatives of the Hispanic community, the Catholic Church, the City Council, the business community, neighborhood associations and the military. Despite this, the focus of the realignment and privatization efforts was not on institutional representation, but individual participation.

In addition, the Clinton Administration maintained close contact with the planning and reuse endeavors. The timely awarding of a $\$ 500,000$ planning grant was essential for establishing the Office of Defense Transition, located in City Hall. The appointment of retired Gen. Paul Roberson as executive director provided expertise, as well as continuity as the community shifted gears from retention to redevelopment. The planning committee also invited a variety of federal and military officials to their strategic planning retreat, held September 9, 1995, at Kelly, and sent representatives to other communities to examine successful redevelopment efforts. Strategic redevelopment plans were completed at the end of 1995. The LRA was formed in early 1996, while privatization plans and local economic development initiatives were scheduled to begin by early 1997. By 2001 the Air Force had completed its drawdown and realignment processes.

The previous discussion is not meant to imply that there was no disagreement about what to do next in San Antonio. There was dissension from the employees' union at the base. However, this seemed to be based on opposition to the concept of privatization in general, instead of specific opposition to community involvement in the realignment process (Hutton 
1995). Eventually the union came to support the idea of employee stock ownership, which was discussed as part of the privatization effort (Driver 1995). The union also seemed to resent the exclusion of institutions, namely itself, in favor of individual participation. However, the labor leadership recognized that if they did not jump on board the privatization effort they would be left behind.

One stumbling block for privatization in place was the existence of the so-called "60-40 rule," which mandated that 60 percent of all depot maintenance funding be allocated to military workers, while private contractors were limited to 40 percent. The late Rep. Frank Tejeda (D-San Antonio) proposed a bill to do away with the rule so that all maintenance work could be reallocated to private contractors. The bill had bipartisan support from area Congressmen including Henry Gonzalez (D), Lamar Smith (R), Henry Bonilla (D), and from Senator Kay Bailey Hutchison (R). Tejeda argued that passage of the legislation would substantially ease the pain of the privatization process for San Antonio and help to keep 6,000 jobs on the base property (Martin 1996, 3B). Unfortunately, Mr. Tejeda suffered an untimely death, and support for the bill in Congress soon diminished. Hence the 60-40 rule was still in existence for much of the decade following the BRAC decisions.

Privatization in place was the top priority due to the large number of jobs involved in the Air Force drawdown, but there are also other sections of the base that are being redeveloped in the fashion of a normal base conversion by an LRA. To this end, the City of San Antonio pushed for the expansion of enterprise zones near the base. Enterprise zones on the East and West sides of town generated 1,595 new jobs and \$285.4 million in new investment between 1988 and 1996 (Konstam 1996, 1F). Finally, there are sections of the base that were transferred to neighboring Lackland AFB, which presented some local accessibility problems, as substantiated by the authors' experience in early April, 1999, when we were unable to get from Kelly to Lackland by previously available access roads.

\section{Sacramento's Privatization in Place}

In 1995, BRAC decided to realign the Air Logistics Center at McClellan AFB, in Sacramento, California, and redirect the repair and maintenance mission to the Tobyhanna Army Depot in Pennsylvania (GAO 1996). The greater Sacramento area had already been hard-hit by previous rounds of base closures, and was already reeling from high unemployment when the news came in the summer of 1995. Besides McClellan, the Oakland Army Depot, Mather AFB, and the Sacramento Army Depot were among the twenty-two base closures that affected the state of California 
during the BRAC era, which will cause the state to lose an estimated $\$ 550$ million annually in income (State of California August 1997). It is also estimated that half the jobs lost in California due to base closure and realignment were due to the realignment of McClellan AFB.

The politically popular solution to the problem of losing McClellan AFB was also privatization in place. However, this was not a unanimous solution. The Mission McClellan Executive Advisory Committee explored a range of other options, including the formation of an economic development corporation. But the White House viewed anything other than privatization as unacceptable. Only through privatization could the jobs and income be maintained with a minimum of displacement (Sorenson 1998). However, this was probably wishful thinking, as the Air Force was found to have erred in the way in which they awarded contracts to prospective tenants by the GAO. The problem seemed to be that they combined all the work into a major contract designed to entice a single, major bidder as opposed to smaller, more specialized service providers (State of California, August 1998). In other words, they put all their eggs in one basket. The GAO would have preferred more competitive bidding in the acquisitions process and project consolidation at existing military facilities to what local officials deemed as necessary (GAO 1996).

In addition, McClellan has a number of environmental problems that prospective private contractors, such as Lockheed-Martin, do not want to be held liable for. The cost of clean up and remediation at McClellan AFB is estimated at almost $\$ 700$ million. Part of the base is a Superfund site (State of California August 1998). This hurts the marketability of former base facilities. Sacramento also suffers from the existence of excess capacity in the air maintenance market, as well as from the existence of the " $60-40$ " rule just like San Antonio.

The inability to totally replace jobs at McClellan stands in stark contrast with a neighboring base conversion. The former Mather AFB was converted to an airport and is a major cargo hub for the region. They also managed to create 3,514 new civilian jobs to replace the 1,012 that were lost when the base closed (GAO 2002). As of 1998, there had yet to be a single new job either created or privatized at McClellan (GAO 1998). Although the most recent GAO report indicates 6,124 jobs have been created since then, there is no explanation as to how (GAO 2002). Presumably, they also changed their strategy to some form of base conversion.

\section{Local Enterprise in Alexandria}

From the time of the closure decision in 1991, Alexandria was determined to exceed expectations and do more than just survive the closure of 
England AFB. The early hiring of the National Organization of Installation Developers (NAID) as consultants proved to be a step in the right direction. NAID provided vital expertise with regard to the structuring of communication patterns and implementation procedures, and was on the cutting edge of multi-solution base conversions. One reason for their success was the focus the consultants placed on job creation and income replacement as the prime goals of the reuse effort. They also made sure that the business community was not excluded, since their role in risking capital and hiring workers was crucial to the establishment of long-term strategic plans and a stable conversion (Morgan and Meyer 1995; Morgan 1996).

The England Authority was established as a municipal enterprise, although technically it is not owned by one city, but is an inter-local operation. The seats on the Authority's ten-member board were divided among the City of Alexandria, the neighboring City of Pineville, the local parish (county), Chamber of Commerce, the affected school districts and the State of Louisiana. The City of Alexandria had a plurality of seats and played the role of lead agency (Morgan and Meyer 1995; Morgan 1996). The authority functions much like an economic development corporation or port authority. A great deal of emphasis was placed on reaching a community consensus and educating the people of central Louisiana through involvement and marketing the opportunities which could be garnered from the successful implementation of a strategic plan.

Initially, the England Authority encountered some resistance from established "good old boy" economic elites and also from local defense workers who had trouble adjusting to the closure (Morgan and Meyer 1995). However, these were mitigated by the reuse effort's ability to create consensus by focusing on community values and the prime goal of job creation. Another problem arose when the Air Force refused to negotiate in good faith for surplus and personal property on the base. However, the England Authority was persistent in its negotiations and challenged the Air Force's agenda of taking as much of the property as they could when they left (Morgan and Meyer 1995; Morgan 1996). The negotiations were not confrontational, but there were what has been described as "vigorous discussions" over the disposal of $\$ 90$ million worth of property, which included $\mathrm{X}$-ray equipment, fire and rescue trucks, chairs, tables and lights (Gargan 1994). The Authority was also very successful in negotiating interim leases with prospective tenants and caretaker agreements in preparation for the military's departure in 1992.

These victories for the Authority were possible for two main reasons. First, by being established as a public authority it had the political legitimacy to negotiate directly with the Air Force for tangible assets that enhanced the value of the facilities. Second, it provided a forum for reaching a consensus 
among those concerned institutions and the general public about what should be done next. This solution was job creation through base conversion. The Authority, along with expert help from their consultants, then negotiated a strategy for reaching the desired end.

Another reason for Alexandria's success was the ability to get large sums of federal and state redevelopment money. Due to state involvement, the Authority was able to get early approval of most of their redevelopment grants. This happened because they were operating under the state's fiscal year, which begins well before the federal fiscal year. Early approval gave them an edge over other communities applying for the same grants. The state sanctioned the Authority as a special district, which effectively established it as a municipal enterprise fund, with the power to issue revenue bonds, contract with firms and other governments and provide economic development incentives. Funds generated from the bonds were used to attract private businesses to the former base facilities.

Conversion solutions on the former base property involved 55 new tenants and included a J.B. Hunt truck driver training school, an aircraft maintenance depot, as well as several minor military missions contracted by the Pentagon (Morgan and Meyer 1995; Morgan 1996; Gargan 1994). Due to the overwhelming demand for England facilities, the former base ran out of hangar space for air- and industrial-related enterprises. These businesses replaced the almost 700 lost civilian jobs and lost income caused by the closure with 1,834 new skilled positions (GAO 2002).

Mixed public and private solutions played a large role in the redevelopment of England. The State of Louisiana reopened and administered the base hospital, which serves the community's poor (Gargan 1994). Education expanded to train the workforce and to provide more opportunity for local people. The newly opened Phoenix Elementary magnet school is one of the best elementary schools in the area and is one of the reuse effort's greatest accomplishments (Morgan and Meyer 1995). Also, higher education found itself a niche on the property. LSU-Alexandria and Northwest Louisiana College expanded to include vocational and air maintenance training. Base housing was converted to a retirement community in order to provide safety and ready access to health care for retired military and other senior citizens (Morgan and Meyer 1995).

The mixed public/private solutions were crafted intentionally so that the community would not become economically dependent upon one industry, as they had been during the Cold War. One of the greatest problems faced by the closure of England was unemployment. This was a primary concern of citizens who attended reuse meetings. A total of a hundred jobs were created from caretaker agreements to maintain the property once the Air Force left the base. As private companies moved onto the property and 
as the state became more involved in the health care and educational sectors of the local economy, there was less pressure for the Authority to directly employ large numbers of people. "The result has been a dramatic surge in jobs, home building and retail sales," according to LSU economics professor, Loren Scott (Gargan 1994, A10).

\section{Discussion}

On the surface it looks as if both Alexandria and San Antonio had gotten off to good starts with their redevelopment efforts. However, in order to be able to claim that policy has been successfully implemented, there must be outcomes resulting from the policy making process. For this reason, we compare the numbers of civilian jobs created and federal grants allocated for redevelopment purposes with the status quo ante numbers of civilian jobs prior to the BRAC decisions in the respective cases (Table 1). The grant dollars are broken down further by the allocating federal agency (Table 2), but the most damning evidence against privatization at former military bases is found by comparing money spent with jobs created.

As shown in Table 1, the cases that illustrate privatized base redevelopment solutions do little to convince the reader that this is a viable solution to defense downsizing. Since 1995, the City of San Antonio has replaced the 10,912 civilian jobs at Kelly AFB with 4,444, at a cost of $\$ 27,206,581$, a recovery rate of 41 percent. Although it is suspected that these new jobs were created through subsequent base conversion on other sections of the former base property, rather than privatization in place, because prior to 1998 government documents show the "jobs created" number at 144 (GAO 1998). This works out to a net loss of 6,468 jobs at a cost of over $\$ 27$ million.

The evidence from the Sacramento case is similarly compelling, though the losses are not quite as bad. Since 1995, the City of Sacramento has lost

Table 1. Jobs Created

\begin{tabular}{lccrrr}
\hline City & $\begin{array}{c}\text { Closure } \\
\text { Decision } \\
\text { Date }\end{array}$ & $\begin{array}{c}\text { Privatization } \\
\text { in Place }\end{array}$ & $\begin{array}{c}\text { Civilian } \\
\text { Jobs } \\
\text { Lost }\end{array}$ & $\begin{array}{c}\text { Civilian } \\
\text { Jobs } \\
\text { Created }\end{array}$ & $\begin{array}{c}\text { Total } \\
\text { Redevelopment } \\
\text { Grants }\end{array}$ \\
\hline Alexandria & 1991 & No & 682 & 1,834 & $\$ 10,926,415$ \\
San Antonio & 1995 & Yes & 10,912 & 4,444 & $\$ 27,206,581$ \\
Sacramento & 1995 & Yes & 8,828 & 6,124 & $\$ 14,473,571$ \\
Source: General Accounting Office. & & & & \\
\hline
\end{tabular}


Table 2. Percent Recovery

\begin{tabular}{lccc}
\hline City & $\begin{array}{c}\text { Civilian } \\
\text { Jobs Lost }\end{array}$ & $\begin{array}{c}\text { Civilian } \\
\text { Created } \\
\text { (as of 2002) }\end{array}$ & $\begin{array}{c}\text { Percent } \\
\text { Recovery }\end{array}$ \\
\hline Alexandria & 682 & 1,834 & $269 \%$ \\
San Antonio & 10,912 & 4,444 & 41 \\
Sacramento & 8,828 & 6,124 & 69 \\
Base Conversion Mean ( $\mathrm{n}=97)$ & 1,776 & 1,092 & 61.5 \\
Source: General Accounting Office. & & & \\
\hline
\end{tabular}

8,828 civilian jobs at McClellan AFB and replaced them with 6,124 new jobs at a cost of $\$ 14,473,571$, a recovery rate of 69 percent. The net job loss was 2,704. Again, the $1998 \mathrm{GAO}$ report shows the number of jobs created at McClellan through privatization to be zero, which suggests that the new jobs came from another source. These partial recoveries are hardly the examples of market efficiency that the proponents of privatization envisioned. It is probably not unreasonable to say that communities opposed to base closure were attempting to ride out the process via the privatization solution. One can hardly blame them for trying.

Our public enterprise case fared somewhat better. The City of Alexandria lost 682 civilian jobs from base closure. They have been replaced with 1,834 new civilian jobs, a recovery rate of 269 percent. This is also a net increase of 1,152 jobs at a cost of $\$ 10,926,415$. The cost is roughly $\$ 5,958$ per new job, which is a much better return on the investment, considering that most jobs created require technical expertise and hence will pay substantially more than this amount back to the community in taxes and multiplier effects. These results should come as no surprise, given that Alexandria is considered by many to be a blueprint of redevelopment success, though it is by no means the top base conversion performer in terms of recovery percentage.

Another indication of success is the source of the redevelopment money. San Antonio and Sacramento received most of their redevelopment money from the Department of Labor, which tends to emphasize job retraining. While this also is considered to be politically popular, it is essentially a form of unemployment insurance rather than a source of economic investment. Alexandria received proportionately greater sums from the Office of Economic Adjustment (OEA) and the Economic Development Agency (EDA), both of which emphasize the creation of new jobs than do other federal agencies. Alexandria also received over a million dollars from the 
Table 3. Grants

\begin{tabular}{lrrrrrr}
\hline & $\begin{array}{c}\text { Office of } \\
\text { Economic } \\
\text { Adjustment }\end{array}$ & $\begin{array}{c}\text { Federal } \\
\text { Aviation } \\
\text { Administration }\end{array}$ & $\begin{array}{c}\text { Economic } \\
\text { Development } \\
\text { Agency }\end{array}$ & $\begin{array}{c}\text { Department } \\
\text { of } \\
\text { Labor }\end{array}$ & Total \\
\hline Alexandria & $\$ 2,652,115$ & $\$ 1,362,500$ & $\$ 6,411,800$ & $\$ 500,000$ & $\$ 10,926,415$ \\
San Antonio & $4,074,181$ & 0 & $8,632,400$ & $14,500,000$ & $27,206,581$ \\
Sacramento & $2,803,511$ & 0 & 0 & $11,670,000$ & $14,473,571$ \\
Source: General Accounting Office. & & & & & \\
\hline
\end{tabular}

Federal Aviation Administration (FAA) in order to maintain its airport. This is crucial to any air maintenance facility because civilian airfields cannot operate without FAA support and oversight. Neither San Antonio nor Sacramento has received a dime from FAA. This is further evidence of delay and inefficient reuse of the facilities.

In addition to the negative evidence provided by the small number of cases that chose privatization in place, the then-General Accounting Office [now the Government Accountability Office] has issued a report detailing the problems with this solution. GAO's argument can be summarized as follows: The purpose behind base closure is to reduce excess capacity. Privatization does not do this, but simply maintains existing capacities in different hands. Not only does privatization in place not reduce excess capacity at the designated sites (or in the private sector for that matter), but it also serves to inflate the costs at the remaining Air Logistics Centers (ALC) due to redundancy. They conclude by saying that if Kelly and McClellan had been closed and the ALC missions consolidated at other bases, the taxpayers could have saved as much as $\$ 468$ million (GAO 1996). This figure, taken with the almost $\$ 42$ million spent on privatization at both bases, comes to well over half a billion dollars - a terribly expensive policy boondoggle.

\section{Conclusions}

The case studies and quantitative evidence presented in the previous pages allow us sufficient information to make some assessments regarding our research proposals. Although they may not be totally conclusive, they are thought provoking nonetheless. The narrative from the case studies provides us with some insight on the first research proposal:

- RP1: The process by which communities choose base conversion solutions to mediate base closure reflects the will of the community. 
The San Antonio case certainly illustrates the political popularity of the privatization solution to base redevelopment. Although this solution was articulated and facilitated by political leaders, there was sufficient grassroots support among citizen participants to indicate that it was also favored from the bottom-up. In the Alexandria case the priorities were a little different. The local polity in this case favored diversifying the economy through a public-private partnership in order to reduce reliance on one particular sector. For them, the multiple-use solution fit their needs better than privatization. Incidentally, the Alexandria case is typical, at least in part, compared to other base conversion cases. This indicates that, as urban regime theorists might argue, cities will attempt to implement the solution to their problems which best fits with that of their normative perceptual orbits. On the other hand, public choice theorists might argue that this is evidence that proves cities behave rationally. However, their assumption that market solutions will prevail because they are the most rational does not hold up to scrutiny. Out of the ninety-seven communities hit by the loss of a major military installation since 1988, only two have selected privatization in place as a solution to their defense downsizing problems, with mixed results at best. The only privatization success case was a minor facility in Ohio, Newark AFB, as detailed by Pidgeon (1996) and Sorenson (1998).

The second and third research propositions are juxtaposed against each other for purposes of contrast:

- RP2: Privatization replaces jobs and income lost as a result of BRAC actions.

- RP3: Public enterprise is a viable alternative to privatization.

Clearly the quantitative data demonstrate that privatization at former military bases has to date hardly been a policy success. The number of jobs created has only been a percentage of what was there before, while the expense has been considerable (over $\$ 41$ million). This result is recognized in the amendments to the 1990 BRAC legislation authorizing a new round of base realignments and closures in 2005, which will not allow privatization in place without special approval of the 2005 BRAC (Schrader 2001; Hansen 2004).

Our single case of Alexandria lends weight to the third research proposal, with over 1,834 jobs being created at the rate of $\$ 5,958$ per new job. There are also less tangible benefits as mentioned above, such as economic diversification (and presumably stability) as well as meeting the community consensus regarding how things ought to be. But one case is hardly generalizable to the population at large, hence the inclusion of base conversion means in Table 2. Though Sacramento outperformed the mean, this was 
done via base conversion after they had given up on privatization. Certainly there is a need for more in-depth studies on the issues of public enterprise and base redevelopment.

\title{
NOTES
}

\begin{abstract}
${ }^{1}$ In order, the steps of the closure process are; 1) Each branch of the military establishes closure criteria and conducts an internal review, resulting in preliminary lists for closure or realignment, which involves redirecting a mission from one facility to another, 2) The Defense Secretary compiles these lists into an overall preliminary closure and realignment list, then forwards it on to the independent commission, 3) The BRAC commission takes the preliminary lists under advisement, conducts regional hearings and constructs the final "hit list." They have extensive powers to reject the preliminary list and start from scratch, or to revise prior BRAC rulings, 4) The president has 45 days to either accept or reject the entire list, and 5) The Congress has 45 days to either accept or reject the entire list (Koven 1992). See Goren (2003) and Hansen (2004) for a more indepth rationale for why Rep. Dick Armey (R-Texas) authored this process in the BRAC legislation.

${ }^{2}$ For a more detailed discussion of presidential electoral politics as it relates to base closure and conversion, see Sorenson 1998; Goren 2003; or Hansen 2004. Sorenson (1998) describes in great deal the election year pursuits of the Clinton administration concerning the San Antonio ALC. Goren's (2003) discussion of McClellan ALC provides more context concerning congressional Democrats who represented the area, and who suffered from BRAC's worst hits. Hansen's (2004) argument echoes the perspectives of both Sorenson and Goren, even though Goren's work had not yet been published at the time of his study.
\end{abstract}

\section{REFERENCES}

Blanchard, Lloyd A., Charles Hinnant, and Wilson Wong. 1998. Market-based Reforms in Government: Toward a Social Subcontract? Administration \& Society 30:483512.

California, State of. 1997. New McClellan Commitment: Aid on the Way, California Base Closure News. Sacramento, CA: Governor's Office of Planning and Research. December.

California, State of. 1998. Regulators Agree on Reuse of Contaminated Property at McClellan, California Base Closure News. Sacramento, CA: Governor's Office of Planning and Research. August.

CBO Papers. 1996. Closing Military Bases: An Interim Assessment. Washington, DC: Congressional Budget Office. December.

CBO Papers. 1997. Paying for Military Readiness and Upkeep: Trends in Operation and Maintenance Spending. Washington, DC: Congressional Budget Office. September.

Driver, Don. 1995. Kelly Union Eyes Stock Ownership, San Antonio Express-News, December 21. 
Ferris, James, and Elizabeth Graddy. 1986. Contracting Out: For What? With Whom? Public Administration Review 46:332-344.

Friedman, Milton, and Rose Friedman. 1979. Free to Choose: A Personal Statement. Orlando, FL: Harcourt Brace Jovanovich.

Fox, Charles J., and Hugh T. Miller. 1995. Postmodern Public Administration: Toward Discourse. Thousand Oaks, CA: Sage Publications.

Gargan, Edward A. 28 November 1994. Military Town Opens Doors as Base Closes, New York Times.

General Accounting Office (GAO). 1996. Air Force Depot Maintenance: Privatizationin-Place Plans Are Costly While Excess Capacity Exists. GAO/NSIAD-97-13. December.

General Accounting Office (GAO). 1997. Military Bases: Lessons Learned from Prior Closure Rounds. GAO/NSAID-97-15. July.

General Accounting Office (GAO). 1998. Military Bases: Status of Prior Base Realignment and Closure Rounds. GAO/NSAID-99-36. December.

General Accounting Office (GAO). 2002. Military Base Closures: Progress in Completing Actions from Prior Realignments and Closures. GAO-02-433. April.

Gitajn, Arthur. 1984. Creating and Financing Public Enterprises. Washington, DC: Government Finance Officers Association.

Goodsell, Charles. 2004. The Case for Bureaucracy, 4th ed. Washington, DC: CQ Press.

Goren, Lilly. 2003. The Politics of Military Base Closings: Not in My District. New York: Peter Lang Publishing.

Gortner, Harold F., Julianne Mahler, and Jeane Bell Nicholson. 1996. Organizational Theory: A Public Perspective, 2nd ed. Ft. Worth, TX: Harcourt Brace.

Hansen, Kenneth N. 2004. The Greening of Pentagon Brownfields: Using Environmental Discourse to Redevelop Former Military Bases. Lanham, MD: Lexington Books.

Hansen, Kenneth N., Tracy A. Skopek, and Mark S. Somma. 1997. The Fundamentals of Policy Implementation at Former Military Bases. American Review of Public Administration 27:377-397.

Herson, Lawrence, and John Bolland. 1996. The Urban Web: Politics, Policy and Theory, 2nd ed. Chicago: Nelson-Hall.

Hutton, Jim. 1995. Union Chief Says Realigning Kelly Way to Keep Jobs. San Antonio Express-News, December 1.

Initial Base Adjustment Strategy Commission (IBASC). 1995. Kelly 21, A Vision for the 21st Century: Strategic Plan for the Redevelopment of Kelly Air Force Base. San Antonio, TX: City of San Antonio.

Judd, Dennis, and Paul Kantor. 1997. The Politics of Urban America: A Reader, 2nd ed. Boston: Allyn \& Bacon.

King, Gary, Robert Keohane, and Sidney Verba. 1994. Designing Social Inquiry: Scientific Inference in Qualitative Research. Princeton, NJ: Princeton University Press.

Konstam, Patricia. 1996. Enterprise Zones Set to Grow, San Antonio Express-News, January 4.

Koven, Steven G. 1992. Base Closings and the Politics-Administration Dichotomy Revisited. Public Administration Review 52:526-533.

Lowi, Theodore. 1969. The End of Liberalism. New York: W.W. Norton.

Martin, Gary. 1996. House Bill Filed to Reject 60-40, San Antonio Express-News, January 6, p. $3 \mathrm{~B}$.

Mayer, Kenneth, and Ann Khademian. 1996. Bringing Politics Back in: Defense Policy and the Theoretical Study of Institutions and Processes. Public Administration Review 56:180-190. 
Mayer, Kenneth. 1995. Closing Military Bases (Finally): Solving Collective Dilemmas Through Negotiation. Legislative Studies Quarterly 20:393-413.

Miller, Hugh T., and James R. Simmons. 1998. The Irony of Privatization. Administration \& Society 30:513-532.

Morgan, Anne. 1996. A personal interview with the NAID consultant for the England Authority, Alexandria, LA.

Morgan, Anne, and James Meyer. 1995. Funding for Military Base Reuse. Alexandria, LA: National Association of Installation Developers (NAID).

Morgan, David R., and Robert E. England. 1988. The Two Faces of Privatization. Public Administration Review 48:979-987.

Osbourne and Ted Gaebler. 1992. Reinventing Government: How the Entrepreneurial Spirit is Transforming the Public Sector. New York: Addison-Wesley.

Pagano, Michael, and Ann O'M. Bowman. 1995. Cityscapes and Capital: The Politics of Urban Development. Baltimore, MD: The Johns Hopkins University Press.

Paul, Gary R. 1992. The Political and Budgetary Effects of Municipal Enterprises in the State of Florida. Ph.D. dissertation, University of Florida.

Pidgeon, Paul D. 1996. Privatization in Place and the Base Closure Community: Newark Air Force Base, Ohio, 1993-1995. Unpublished master's thesis, Air Force Institute of Technology.

Pierce, Lawrence W. "Chip,” and Kenneth L. Rust. 1991. Government Enterprises. Local Government Finance, Concepts and Practices.

Ripley, Randall, and Grace Franklin. 1991. Congress, the Bureaucracy and Public Policy, 5th ed. Pacific Cove, CA: Brooks/Cole Publishing.

Schrader, Esther. 2001. Pentagon Plan Seeks New Base Shutdowns. The Los Angeles Times, July 27.

Sorenson, David. 1998. Shutting Down the Cold War: The Politics of Military Base Closure. New York: St. Martin's Press.

Stein, Robert M. 1990. Urban Alternatives. Pittsburgh, PA: University of Pittsburgh Press.

Stone, Clarence, and Heywood T. Sanders, eds. 1987. The Politics of Urban Development. Lawrence: University Press of Kansas.

Stumm, Theodore J., and Henry B. Thomas. 1999. Benchmarking Florida's Electric Power Enterprises: A Comparison of Public and Private Sector Efficiency. Public Works Management and Policy.

Stumm, Theodore J. 1996. Municipal Enterprise Activities as Revenue Generators: A Different View. American Review of Public Administration 26:477-488. 
